\title{
PENGARUH KAPASITAS SUMBER DAYA MANUSIA DAN KOMITMEN ORGANISASI TERHADAP KUALITAS LAPORAN KEUANGAN PEMERINTAH DAERAH PADA BADAN PENGELOLA KEUANGAN DAN ASET DAERAH (BPKAD) KOTA MANADO
}

\author{
Rivaldy Manimpurung ${ }^{1}$, Lintje Kalangi ${ }^{2}$, Natalia Gerungai ${ }^{3}$ \\ 1,2,3 Jurusan Akuntansi, Fakultas Ekonomi dan Bisnis, Universitas Sam Ratulangi, Jl. Kampus Bahu, Manado, \\ 95115, Indonesia \\ E-mail: manimpurungrivaldy242@gmail.com
}

\begin{abstract}
The quality of government financial reporting is a normative prerequisite for the preparation of financial statements so that the resulting accounting information can be beneficial to users of financial statements. This is the aim of recognizing the effect of human resources and organizational commitment toward the quality of regional financial reports in $B P K A D$ in Manado. The data collected through questionnaire distributions to 64 respondents were financial managers at BPKAD in Manado City. The data were analyzed using multiple linear regression analysis method with SPSS 17 program. The results showed that SDM Capacity has no positive effect on LKPD Quality and Organization Commitment positively and significantly affect the quality of Local Government Financial Reporting at BPKAD in Manado City.

Keywords: Human Resource Capacity, Organizational Commitment, Quality of Financial

Statement.
\end{abstract}

\section{PENDAHULUAN}

Pemerintah daerah adalah suatu entitas pelaporan keuangan publik yang harus mempertanggungjawabkan tata kelola keuangan daerah kepada para stakeholder (pemangku kepentingan) sebagaimana diatur dalam Undang-Undang Nomor 17 Tahun 2003 tentang Keuangan Negara dan Undang-Undang Nomor 1 Tahun 2004 tentang Perbendaharaan Negara. Tuntutan yang semakin besar terhadap akuntabilitas publik ini digunakan untuk memberikan informasi tentang keuangan dari suatu entitas yang berguna bagi sejumlah besar pemakai dalam membuat dan mengevaluasi keputusan mengenai alokasi sumber daya yang dibutuhkan suatu entitas dalam aktivitasnya untuk mencapai tujuan (Sujarweni, 2015:88).

Salah satu faktor yang dapat meningkatkan kualitas laporan keuangan daerah adalah kapasitas sumber daya manusia. Kapasitas sumber daya manusia adalah kemampuan sumber daya manusia untuk melaksanakan tugas dan tanggung jawab yang diberikan kepadanya dengan bekal pendidikan, pelatihan, dan pengalaman yang cukup memadai. Sumber daya manusia merupakan pilar penyangga utama sekaligus penggerak roda organisasi dalam usaha mewujudkan visi dan misi serta tujuan dari organisasi tersebut. Sumber daya manusia merupakan salah satu elemen organisasi yang sangat penting, oleh karena itu harus dipastikan bahwa pengelolaan sumber daya manusia dilakukan sebaik mungkin agar mampu memberikan kontribusi secara optimal dalam upaya pencapaian tujuan organisasi.

Informasi akuntansi yang berkualitas tentu saja dihasilkan oleh sumber daya manusia yang memiliki kompetensi serta latar belakang pendidikan dibidang ekonomi akuntansi agar informasi yang dihasilkan tersebut sesuai dengan sistem akuntansi yang berlaku umum, bebas dari kesalahan baik material maupun non material dan terhindar dari kecurangan baik yang di sengaja maupun tidak di sengaja. Sumber daya manusia yang memiliki kompetensi tidak hanya dilihat dari latar belakang pendidikan namun juga dapat dilihat dari pelatihan- 
pelatihan yang diikuti serta pengalaman. Semakin tingginya kompetensi aparatur pengelola keuangan maka semakin memungkinkan menghasilkan informasi akuntansi dalam laporan keuangan yang berkualitas. Dalam lingkup keuangan daerah. kapasitas sumber daya manusia merupakan faktor penentu keberhasilan pengelolaan keuangan daerah. Namun selama ini yang terjadi adalah ASN yang bekerja tidak mendapatkan pengalaman bekerja atau mendapatkan bekal pengetahuan yang cukup dan kurangnya kesempatan untuk mendapatkan pendidikan/pelatihan yang sesuai dengan tugas/bidang bekerjanya. Faktor selanjutnya yang dapat meningkatkan kualitas laporan keuangan pemerintah daerah yaitu komitmen organisasi. Komitmen dari pemerintah daerah dalam hal ini merupakan kegiatan dari satuan kerja perangkat daerah (SKPD) untuk melakukan perubahan sesuai dengan adanya perubahan peraturan perundang-undangan.

Berdasarkan latar belakang masalah yang telah diuraikan, maka penulis merumuskan masalah yang akan di bahas yaitu Bagaimana Apakah Kapasitas Sumber Daya Manusia dan Komitmen Organisasi berpengaruh terhadap Kualitas LKPD pada BPKAD.?

Adapun tujuan penelitian ini adalah untuk Untuk mengetahui pengaruh kapasitas sumber daya manusia bidang akuntansi dan komitmen organisasi terhadap kualitas laporan keuangan daerah.

\section{TINJAUAN PUSTAKA}

\subsection{Akuntansi}

Menurut Sumarsan (2013:1) menjelaskan bahwa Akuntansi adalah suatu seni untuk mengumpulkan, mengidentifikasikan, mengklasifikasikan, mencatat transaksi serta kejadian yang berhubungan dengan keuangan, sihingga dapat menghasilkan informasi yaitu laporan keuangan yang dapat digunakan oleh pihak-pihak yang berkepentingan. Akuntansi adalah suatu aktivitas jasa yang terdiri dari mencatat, mengklasifikasikan, dan melaporkan kejadian atau transaksi ekonomi yang akhirnya akan menghasilkan suatu informasi keuangan yang dibutuhkan oleh pihak-pihak tertentu untuk pengambilan keputusan. (Sujarweni, 2015 dalam bukunya berjudul "Akuntansi Sektor Publik").

\subsection{Akuntansi Sektor Publik}

Menurut PP No. 24 Tahun 2005, Akuntansi Sektor Publik didefinisikan sebagai mekanisme teknik dan analisis akuntansi yang diterapkan pada pengelolaan dana masyarakat di lembagalembaga tinggi Negara dan departemen-departemen di bawahnya, pemerintah daerah, BUMN, BUMD, LSM, dan yayasan social maupun proyek-proyek kerjasama sektor publik dan swasta.

\subsection{Kapasitas Sumber Daya Manusia}

Sumber daya manusia adalah orang yang siap, mau dan mampu memberikan sumbangan dalam usaha pencapain tujuan organisasional, sumber daya manusia mencangkup tiga aspek, yaitu pendidikan, pengalaman dan pelatihan. Sumber daya manusia harus baik karena sumber daya manusia yang baik akan menunjukkan kapasitas sumber daya yang baik juga. Manusia bertanggung jawab untuk mengelola organisasi, oleh karena itu sumber daya manusia merupakan elemen penting dan selalu ada dalam organisasi (Hullah, dkk. 2012).

\subsection{Komitmen Organisasi}

Komitmen organisasi adalah suatu unit terkoordinasi yang terdiri dari dua orang atau lebih dan berfungsi mencapai suatu sasaran atau tujuan tertentu. Komitmen organisasi merupakan nilai personal, yang kadang-kadang mengacu pada sikap loyal pada perusahaan/organisasi atau komitmen pada peruahaan itu (Hapsari, 2011).

\subsection{Kualitas Laporan Keuangan Pemerintah Daerah}

Laporan keuangan pemerintah daerah adalah suatu bentuk pertanggungjawaban pemerintah daerah kepada stakeholder yang didalamnya mencakup berbagai macam pekerjaan yang membutuhkan keuangan (Yusuf, 2013:1). Pengguna informasi akuntansi 
harus dapat memperoleh pemahaman mengenai kondisi keuangan dan hasil operasional perusahaan lewat pelaporan keuangan (Hery, 2014:35).

\subsection{Kerangka Konseptual}

Berdasarkan pada telaah literatur dan beberapa hasil penelitian sebelumnya, maka kerangka pemikiran menggambarkan hubungan antara variabel independen dan variabel dependen. Variabel independen penelitian meliputi Kapasitas Sumber Daya Manusia dan Komitmen Organisasi. Sedangkan variabel dependen adalah Kualitas Laporan Keuangan Pemerintah Daerah. Kerangka konseptual dapat ditunjukkan pada gambar 2.1 berikut.

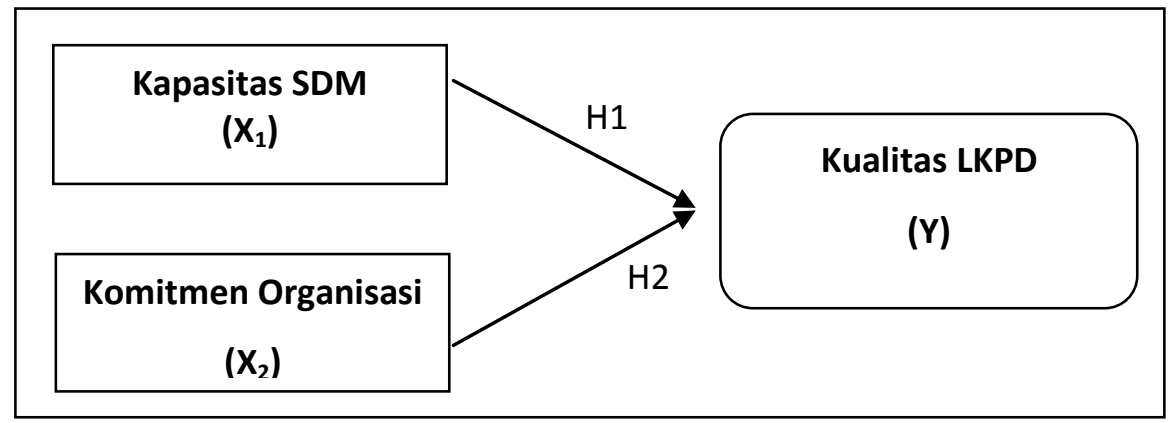

\subsection{Hipotesis}

2.7.1 Pengaruh Kapasitas Sumber Daya Manusia terhadap Kualitas Laporan Keuangan Pemerintah Daerah.

Laporan keuangan dikatakan berkualitas apabila informasi yang disajikan dalam laporan keuangan tersebut dapat dipahami, memenuhi kebutuhan pemakainya dalam pengambilan keputusan, bebas dari pengertian yang menyesatkan, kesalahan material serta dapat diandalkan sehingga laporan keuangan tersebut dapat dibandingkan dengan periodeperiode sebelumnya. Oleh karena itu, kualitas laporan keuangan tidak terlepas dari kapasitas sumber daya manusia (dalam hal ini akuntan), sebagai individu yang bertanggungjawab dalam penyusunan laporan keuangan. dari penjelasan diatas dapat dirumuskan hipotesisi sebagai berikut

H1: Kapasitas Sumber Daya Manusia berpengaruh terhadap Kualitas Laporan Keuangan Pemerintah Daerah.

\subsubsection{Pengaruh Komitmen Organisasi terhadap Kualitas Laporan Keuangan Pemerintah Daerah.}

Komitmen organisasi, sebagaimana disebutkan di atas, mendorong pemimpin dan aparatur untuk memiliki kontribusi lebih bagi organisasi sehingga harusnya hal tersebut memberikan dampak terhadap peningkatan kualitas kinerja aparatur. Hal itu harusnya membawa dampak positif bagi aparatur yang memiliki wewenang dalam bidang pengelolaan dan penyusunan transaksi keuangan. Penelitian ini bertujuan untuk mengetahui pengaruh kapasitas sumber daya manusia terhadap kualitas laporan keuangan pemerintah daerah pada BPKAD. Berdasarkan uraian diatas dapat dirumuskan hipotesis sebagai berikut:

H2: Komitmen Organisasi berpengaruh terhadap Kualitas Laporan Keuangan Pemerintah Daerah.

\subsection{Penelitian Terdahulu}

Warih Komarasari (2017), dengan penelitian berjudul Pengaruh Kapasitas Sumber Daya Manusia, Pemanfaatan Teknologi Informasi Dan Pengendalian Intern Akuntansi Terhadap Keterandalan Pelaporan Keuangan Daerah (Pada SKPD Kabupaten Bantul Bagian Akuntansi Dan Keuangan). Hasil penelitian menunjukan Variabel pemanfaatan teknologi informasi dan pengendalian intern akuntansi berpengaruh secara signifikan terhadap keterandalan pelaporan keuangan pemerintah daerah. Sedangkan kapasitas sumber daya manusia tidak berpengaruh secara signifikan terhadap keterandalan pelaporan keuangan 
pemerintah daerah. Persamaannya dengan penelitian ini adalah menggunakan variable independen Kapasitas SDM dan metode penelitian, sedangkan perbedaanya adalah Tidak menggunakan variable independen pemanfataan TI dan pengendalian intern akuntansi.

Dwi Swasana Ramadhan (2016), dengan penelitian berjudul Pengaruh Kapasitas Sumber Daya Manusia, Pemanfaatan Teknologi Informasi, dan Sistem Pengendalian Intern Terhadap Nilai Informasi,Keterandalan, dan Ketepatwaktuan Laporan Keuangan (Studi Kasus di Kabupaten Banjarnegara). Variabel pemanfaatan teknologi informasi dan sistem pengendalian intern berpengaruh secara signifikan terhadap variable dependen, sedangkan kapasitas sumber daya manusia tidak berpengaruh secara signifikan terhadap variable dependen. Persamaanya dengan Menggunakan variable independen Kapasitas SDM dan metode penelitian, sedangkan perbedaanya adalah menggunakan variable independen pemanfataan TI dan system pengendalian intern.

\section{METODE PENELITIAN}

\subsection{Jenis Penelitian}

Penelitian ini merupakan penelitian kuantitatif yang merupakan metode penelitian yang digunakan untuk meneliti pada populasi atau sampel tertentu, teknik pengambilan sampel pada umumnya dilakukan secara acak, pengumpulan data menggunakan instrument penelitian, analisis data bersifat kuantitatif/statistik dengan tujuan untuk menguji hipotesis yang telah ditetapkan (Sugiyono, 2016).

\subsection{Tempat dan Waktu Penelitian}

Lokasi penelitian dilakukan di Badan Pengelola Keuangan dan Aset Daerah (BPKAD) di Kota Manado dalam bentuk wawancara dan penyebaran angket atau kuesioner terstruktur yang telah disiapkan sebelumnya untuk melakukan penelitian. Waktu penelitian adalah bulan Oktober sampai dengan November 2017.

\subsection{Prosedur Penelitian}

Adapun prosedur penelitian yang digunakan dalam penelitian ini adalah:

1. Mengidentifikasi dan merumuskan masalah penelitian.

2. Melakukan telaah terhadap teori dan penelitian sebelumnya yang berkaitan dengan masalah yang diteliti.

3. Merancang metodologi penelitian dan teknik pengumpulan data.

4. Memberikan kuesioner kepada Pegawai/Aparatur BPKAD

5. Mentabulasi data yang telah disimpulkan dan dilakukan analisis.

6. Berdasarkan hasil analisis mengambil kesimpulan dan diberikan saran-saran yang perlu terhadap hasil penelitian.

\subsection{Populasi dan Sampel Penelitian}

\subsubsection{Populasi}

Menurut Sugiyono (2016:119), populasi adalah wilayah generalisasi yang terdiri atas obyek atau subyek yang mempunyai kualitas dan karakteristik tertentu yang ditetapkan oleh peneliti untuk dipelajari dan kemudian ditarik kesimpulannya. Adapun populasi dalam penelitian ini adalah dalam lingkungan pemerintah kota manado. Unit penelitian individu, sedangkan obyek penelitian atau responden yang menjadi sumber data adalah pegawai, pimpinan/pelaksana, dan pengawas pada instansi tersebut.

\subsubsection{Sampel}

Sampel adalah bagian dari jumlah karakteristik yang dimiliki oleh populasi tersebut (Sigiyono 2016:120). Kriteria responden dalam penelitian ini adalah pegawai yang bekerja dan melaksanakan tugas dan fungsi sebagai pengelola keuangan di BPKAD. Responden dalam penelitian ini adalah seluruh aparatur sipil negara sebanyak 64 orang sudah termsuk 4 kepala bidang dan 15 kepala sub bidang dan 45 ASN fungsional pada BPKAD.

\subsection{Jenis Data}


Jenis data penelitian yang digunakan dalam penelitian ini adalah jenis data kuantitatif yang diukur dalam suatu skala numerik (angka) melalui kuesioner yang disebarkan oleh peneliti kepada aparatur pengelola keuangan pada BPKAD di Kota Manado.

\subsection{Sumber Data}

Sumber data dalam penelitian yaitu data primer dan data sekunder. Data primer dalam penelitian ini diperoleh melalui penyebaran kuesioner, wawancara atau tanya jawab dari sumbernya. Sumber data primer dalam penelitian ini adalah aparatur pengelola keuangan pada SKPD di Kota Manado. Data Sekunder adalah data yang diperoleh peneliti secara tidak langsung melalui media perantara yaitu melalui hasil-hasil penelitian, buku-buku, artikel, dan berbagai referensi-referensi terkait yang relevan dengan masalah yang diangkat.

\subsection{Teknik Pengumpulan Data}

Teknik pengumpulan data dalam penelitian ini adalah menggunakan kuesioner dan wawancara. Menurut Creswell dalam Sugiyono (2016:192) kuesioner merupakan teknik pengumpulan data di mana partisipasi/responden mengisi pertanyaan atau pernyataan kemudian setelah diisi dengan lengkap mengembalikan kepada peneliti. Kuesioner disebarkan kepada aparatur pengelola keuangan pada BPKAD di Kota Manado.

\section{HASIL PENELITIAN DAN PEMBAHASAN}

\subsection{Uji Kualitas Data}

\subsubsection{Uji Validitas}

Uji validitas digunakan untuk menguji sah atau tidaknya suatu kuesioner. Pengujian ini menggunakan rumus person product moment. Tabel berikut menunjukkan hasil uji validitas dari dua variabel independen dengan 64 responden.

Hasil Uji validitas Kapasitas Sumber Daya Manusia $\left(\mathbf{X}_{1}\right)$

\begin{tabular}{|c|c|c|c|}
\hline Item pertanyaan & $\mathbf{r}_{\text {hitung }}$ & $\mathbf{r}_{\text {tabel }}$ & Keterangan \\
\hline 1 & 0,637 & 0,246 & Valid \\
\hline 2 & 0,673 & 0,246 & Valid \\
\hline 3 & 0,461 & 0,246 & Valid \\
\hline 4 & 0,366 & 0,246 & Valid \\
\hline 5 & 0,291 & 0,246 & Valid \\
\hline 6 & 0,258 & 0,246 & Valid \\
\hline
\end{tabular}

\section{Hasil Uji Validitas Komitmen Organisasi $\left(\mathbf{X}_{2}\right)$}

\begin{tabular}{|c|c|c|c|}
\hline Item Pertanyaan & $\mathbf{r}_{\text {hitung }}$ & $\mathbf{r}_{\text {tabel }}$ & Keterangan \\
\hline 1 & 0,354 & 0,312 & Valid \\
\hline 2 & 0,520 & 0,312 & Valid \\
\hline 3 & 0,263 & 0,312 & Valid \\
\hline 4 & 0,520 & 0,312 & Valid \\
\hline 5 & 0,640 & 0,312 & Valid \\
\hline 6 & 0,640 & 0,312 & Valid \\
\hline
\end{tabular}

Hasil Uji Validitas Kualitas Laporan Keuangan Pemerintah Daerah Kota Manado (Y)

\begin{tabular}{|c|c|c|c|}
\hline Item pertanyaan & $\mathbf{r}_{\text {hitung }}$ & $\mathbf{r}_{\text {tabel }}$ & Keterangan \\
\hline 1 & 0,679 & 0,312 & Valid \\
\hline 2 & 0,829 & 0,312 & Valid \\
\hline 3 & 0,909 & 0,312 & Valid \\
\hline 4 & 0,891 & 0,312 & Valid \\
\hline 5 & 0,818 & 0,312 & Valid \\
\hline
\end{tabular}

Berdasarkan hasil perhitungan SPSS 17 pada tabel 4.5 sampai dengan 4.7 menunjukkan hasil yang baik dengan nilai $\mathrm{N}=40$, taraf signifikasi 0,05 dan nilai rtabel. Tabel tersebut menunjukkan bahwa semua pertanyaan dari variabel independen (Kapasitas sumber daya manusia dan komitmen organisasi) dan variabel dependen (kualitas laporan keuangan 
pemerintah daerah) adalah valid karena rhitung > rtabel. Hal ini menunjukkan bahwa semua pertanyaan di variabel tersebut dapat digunakan dalam penelitian.

\subsubsection{Uji Reliabilitas}

Reliabilitas adalah indikator untuk mengukur kuesioner yang merupakan indikator dari suatu variabel. Alat ukur dikatakan reliabel jika nilai koefisien alpha di atas 0,5. Berikut hasil uji reliabilitas atas variabel penelitian yang diolah dengan menggunakan SPSS 17. Hasil dari uji reliabilitas untuk variabel Kapasitas Sumber Daya Manusia dapat dilihat pada tabel 4.8 berikut ini:

\section{Hasil uji reliabilitas Kapasitas Sumber Daya Manusia}

\begin{tabular}{|r|r|}
\hline $\begin{array}{c}\text { Cronbach's } \\
\text { Alpha }\end{array}$ & N of Items \\
\hline .369 & 6 \\
\hline
\end{tabular}

Hasil uji reliabilitas menunjukkan Cronbach's Alpha sebesar 0.369 dan dinyatakan realibel karena nilainya lebih besar dari 0,60 $(0,369>0,60)$.

Selanjutnya uji reliabilitas untuk variabel Komitmen Organisasi dapat dilihat di tabel 4.9 berikut ini :

\section{Hasil uji reliabilitas Komitmen Organisasi

\begin{tabular}{|r|r|}
\hline $\begin{array}{c}\text { Cronbach's } \\
\text { Alpha }\end{array}$ & N of ltems \\
\hline .310 & 6 \\
\hline
\end{tabular}

Hasil uji reliabilitas menunjukkan Cronbach's Alpha sebesar 0.310 dan dinyatakan realibel karena nilainya lebih besar dari $0,60(0,310>0,60)$.

Selanjutnya uji reliabilitas untuk variabel Kualitas Laporan Keuangan Pemerintah Daerah Kota Manado dapat dilihat di tabel 4.10 berikut ini:

Hasil uji reliabilitas kualitas Laporan Keuangan Pemerintah Daerah Kota Manado

\begin{tabular}{|r|r|}
\hline $\begin{array}{c}\text { Cronbach's } \\
\text { Alpha }\end{array}$ & N of Items \\
\hline .882 & 5 \\
\hline
\end{tabular}

Hasil uji reliabilitas menunjukkan Cronbach's Alpha sebesar 0.882 dan dinyatakan realibel karena nilainya lebih besar dari 0,60 $(0,882>0,60)$.

\subsection{Uji Asumsi Klasik}

\subsubsection{Uji Normalitas}

Uji normalitas bertujuan untuk menguji apakah dalam model regresi, variabel pengganggu atau residual mempunyai distribusi normal. Uji normalitas data yang digunakan dalam penelitian ini yaitu metode One-Sample Kolmogorov-Smirnov Test dan metode grafik (P-P Plot). Cara untuk mendeteksinya adalah dengan melihat nilai signifikansi residual. Jika nilai signifikansi lebih dari 0.05 , maka residual terdistribusi secara normal. 


\section{Hasil Uji Normalitas}

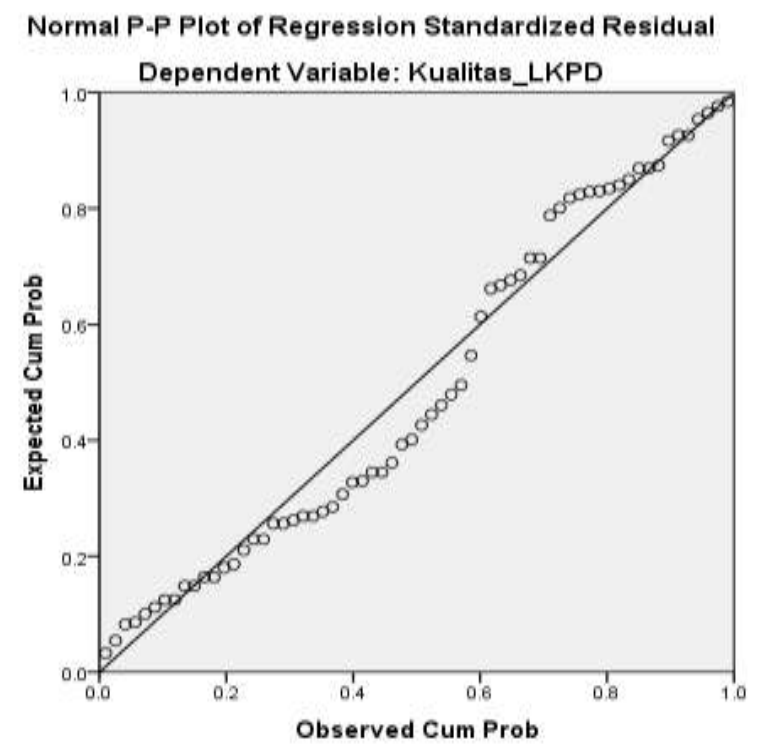

Berdasarkan grafik pada gambar 4.1, dapat dilihat bahwa titik-titik menyebar di sekitar garis dan mengikuti garis diagonal. Oleh karena itu, model regresi memenuhi asumsi normalitas.

\subsubsection{Uji Multikolonieritas}

Uji multikolinieritas bertujuan untuk menguji apakah dalam model regresi ditemukan adanya korelasi yang tinggi atau sempurna antar variabel independen. Cara untuk mengetahui ada atau tidaknya gejala multikolinieritas antara lain dengan melihat nilai variance inflation factor (VIF) dan tolerance. Apabila nilai VIF kurang dari 10 dan tolerance lebih dari 0.1, maka dikatakan tidak terjadi multikolinieritas.

\section{Hasil uji multikolonieritas}

\begin{tabular}{|c|c|c|}
\hline Variabel & Tolerance & VIF \\
\hline Kapasitas SDM & 0,674 & 1,485 \\
\hline Komitmen organisasi & 0,674 & 1,485 \\
\hline
\end{tabular}

Berdasarkan tabel di atas dapat dilihat bahwa nilai tolerance dari variabel independen lebih dari 0.1 dan nilai VIF kurang dari 10. Hal ini menunjukkan bahwa tidak terjadi multikolinieritas.

\subsubsection{Uji Heteroskedastisitas}

Uji heteroskedastisitas bertujuan untuk melihat sebarab titik-titik secara acak pada grafik yang tidak membentuk pola secara menentu.

\section{Hasil uji heteroskedastisitas}

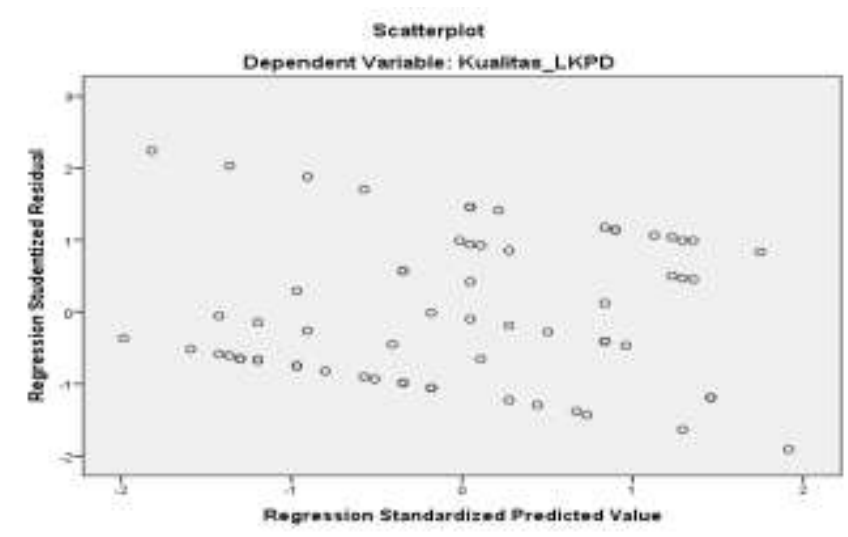


Berdasarkan gambar 4.2 di atas, maka tidak terjadi heteroskedastisitas karena titiktitik menyebar di atas dan di bawah nilai angka nol (0) pada sumbu Ydan tidak membentuk pola.

\subsection{Uji Hipotesis}

Coefficients $^{a}$

\begin{tabular}{|c|c|c|c|c|c|c|}
\hline \multirow{2}{*}{\multicolumn{2}{|c|}{ Model }} & \multicolumn{2}{|c|}{ Unstandardized Coefficients } & \multirow{2}{*}{$\begin{array}{c}\text { Standardized } \\
\text { Coefficients } \\
\text { Beta }\end{array}$} & \multirow[t]{2}{*}{$\mathrm{T}$} & \multirow[t]{2}{*}{ Sig. } \\
\hline & & B & Std. Error & & & \\
\hline \multirow[t]{3}{*}{1} & (Constant) & 14.614 & 3.684 & & 3.967 & .000 \\
\hline & Kapasitas_SDM & -.169 & .153 & -.160 & -1.100 & .276 \\
\hline & Komitmen_Organisasi & .460 & .157 & .428 & 2.940 & .005 \\
\hline
\end{tabular}

a. Dependent Variable: Kualitas_Laaporan_Keuangan_Pemerintah_Daerah

Uji parsial digunakan untuk mengetahui apakah variabel independen (X) secaraparsial berpengaruh signifikan terhadap variabel dependen (Y). Berdasarkan hasil uji t pada tabel 4.13, nilai sig, untuk pengaruh Kapasitas Sumber Daya Manusia(X1) Terhadap Y adalah sebesar $0.276>0.05$ dan nilai t hitung $-1.100<\mathrm{t}$ tabel 2.000 , sehingga dapat disimpulkan bahwa $\mathrm{H} 1$ ditolak yang berarti tidak terdapat pengaruh X1 terhadap Y.

Nilai sig. untuk pengaruh pengetahuan Komitmen Organisasi (X2) terhadap Y adalah sebesar $0.005<0.005$ dan $t$ hitung $0,2940>2.000$, sehingga dapat disimpulkan bahwa $\mathrm{H} 2$ diterima berarti terdapat pengaruh $\mathrm{X} 2$ terhadap $\mathrm{Y}$.

\subsection{Pembahasan Hasil Penelitian}

\subsubsection{Pengaruh Kapasitas Sumber Daya Manusia Terhadap Kualitas Laporan Keuangan Pemerintah Daerah}

Berdasarkan hasil uji t menunjukkan bahwa nilai thitung lebih kecil dari nilai ttabel $(1.100<2.000)$ dan nilai signifikansi yang lebih besar daripada nilai signifikan 5\% (0.276> 0.05). Hal ini menunjukkan bahwa kapasitas sumber daya manusia secara parsial tidak mempunyai pengaruh terhadap kualitas laporan keuangan pemerintah daerah.

Sumber daya manusia adalah orang yang siap, mau dan mampu memberikan sumbangan dalam usaha pencapain tujuan organisasional, sumber daya manusia mencangkup tiga aspek, yaitu pendidikan, pengalaman dan pelatihan. Sumber daya manusia harus baik karena sumber daya manusia yang baik akan menunjukkan kapasitas sumber daya yang baik juga. Manusia bertanggung jawab untuk mengelola organisasi, oleh karena itu sumber daya manusia merupakan elemen penting dan selalu ada dalam organisasi (Hullah, dkk. 2012).

Kapasitas sumber daya manusia yang baik belum tentu akan menghasilkan kualitas laporan keuangan yang baik. Hal terbukti dengan penelitian yang dilakukan di BPKAD Kota Manado, dimana kapasitas sumber daya manusia di BPKAD Kota sudah memadai tetapi tidak mempengaruhi kualitas laporan keuangan pemerintah daerah. Hal ini dikarenakan SDM yang berada di BPKAD Kota Manado masih tergolong baru dan SDM yang berpengalaman dalam menyusun laporan keuangan telah dimutasi. Sehingga kapasitas SDM di BPKAD Kota Manado tidak mempengaruhi kualitas laporan keuangan yang dihasilkan. Hasil penelitian ini mendukung hasil penelitian sebelumnya yaitu Zuliarti, 2012 yang menyatakan bahwa kapasitas SDM tidak berpengaruh positif signifikan terhadap keteradalan pelaporan keuangan pemerintah daerah pada Kabupaten Kudus.Penelitian lainya yang tidak mendukung adalah penelitian Karmila, Tanjung, Darlis (2014) memberikan bukti empiris bahwa kapasitas SDM tidak berpengaruh signifikan terhadap keterandalan pelaporan keuangan pemerintah daerah, hal ini di sebabkan karena kondisi SDM di sub bagian akuntansi/tata usaha keuangan 
pemerintah pada Provinsi Riau yang belum mendukung meskipun pemerintah provisi riau telah memperbantukan lebih kurang tujuh puluh tenaga akuntansi yang tersebar di satkersatker namun belum optimal.

\subsubsection{Pengaruh Komitmen Organisasi Terhadap Kualitas Laporan Keuangan Pemerintah Daerah}

Hasil perhitungan regresi menunjukkan nilai koefisien regresi positif dari variabel Komitmen Organisasi dan Kualitas Laporan Keuangan Pemerintah Daerah. Uji t menunjukkan bahwa nilai thitung lebih besar daripada nilai ttabel $(0.2940>2.000)$ dan nilai signifikansi yang lebih kecil daripada nilai signifikan $5 \% \quad(0.005<0.005)$. Hal ini menunjukkan bahwa komitmen organisasi secara parsial mempunyai pengaruh terhadap kualitas laporan keuangan pemerintah daerah.

Pegawai yang memiliki komitmen tinggi terhadap organisasinya akan berusaha meningkatkan kinerjanya serta menunjukkan dedikasi dan dukungan yang kuat dalam pencapaian tujuan organisasi dengan memaksimalkan kemampuan yang dimilikinya. Sebaliknya komitmen pegawai yang rendah cenderung mengakibatkan terjadinya penurunan kinerja. Hal ini menunjukan bahwa Komitmen Organisasi yang tinggi dapat mendorong pegawai untuk meningkatkan kapasitasnya agar tujuan organisasi dapat tercapai, sehingga semakin tinggi Komitmen Organisasi, maka semakin tinggi pula Kapasitas Sumber Daya Manusia dan Kualitas Laporan Keuangan Pemerintah Daerah.

Berdasarkan hasil penelitian ini kualitas laporan keuangan pemerintah daerah dipengaruhi oleh komitmen organisasi secara parsial. Dimana hasil penelitian ini sejalan dengan (sopiah, 2008) yang menyatakan bahwa komitmen organisasi baik yang tinggi maupun yang rendah akan berdampak pada karyawan itu sendiri dan organisasi. karyawan yang berkomitmen tinggi pada organisasi akan menimbulkan kinerja organisasi yang tinggi

Hasil penelitian ini juga sejalan dengan penelitian Nivo (2013) yang menujukan bahwa komitmen oeganisasi berpengaruh signifikan positif terhadap kualitas laporan keuangan pemerintah daerah.

Selain itu juga, Penelitian lainnya yang meneliti kualitas Laporan Keuangan Pemerintah Daerah dengan variabel yang berbeda juga dilakukan oleh Elvyra Zeyn (2011), Ifa Ratifah dan M. Ridwan (2012) dalam tulisannya meneliti kualitas laporan keuangan dengan menambahkan variabel komitmen organisasi sebagai pemoderasi. Dan hasilnya menunjukkan bahwa dengan menambahkan komitmen organisasi sebagai variabel moderasi memiliki pengaruh yang signifikan terhadap kualitas laporan keuangan.

\section{KESIMPULAN DAN SARAN}

\subsection{Kesimpulan}

Berdasarkan hasil penelitian yang telah diuraikan sebelumnya, maka dapat diambil kesimpulan sebagai berikut:

1. Kapasitas Sumber Daya Manusia tidak berpengaruh secara parsial kualitas laporan keuangan pemerintah daerah kota manado di BPKAD. Hal ini ditunjukkan nilai t hitung lebih kecil daripada nilai t tabel $(1100<2.000)$ dan nilai signifikansi yang lebih besar daripada nilai signifikansi 5\% (0.176>0.05).

2. Dan variabel komitmen organisasiberpengaruh secara parsial kualitas laporan keuangan pemerintah daerah kota manado di BPKAD. Hal ini ditunjukkan nilai t hitung lebih besar daripada nilai t tabel $(0.2940>2.000)$ dan nilai signifikansi yang lebih kecil daripada nilai signifikansi $5 \%(0.005<0.005)$.

\subsection{Saran}

Berdasarkan kesimpulan di atas diharapkan penelitian selanjutnya dapat menyajikan hasil penelitian yang berkualitas dengan adanya saran-saran mengenai beberapa hal: 
1. Untuk penelitian selanjutnya bisa menggunakan sampel yang lebih banyak lagi, dibandingkan penelitian ini, agar hasil yang didapatkan bisa lebih akurat.

2. Penelitian ini tidak melakukan wawancara langsung pada masing-masing responden, tetapi sebagai disarankan pada penelitian selanjutnya bisa dilakukan wawancara secara langsung

3. Penelitian selanjutnya dapat menggunakan variabel bebas lainnya sehingga untuk selanjutnya dapat ditemukan variabel baru yang akan mempengaruhi kualitas laporan keuangan pemerintah daerah.

\section{DAFTAR PUSTAKA}

Darlis 2014. Pengaruh Kapasitas Sumber Daya Manusia, Pemanfaatan Teknologi Informasi dan Pengendalian Intern terhadap Keterandalan Pelaporan Keuangan Pemerintah Daerah (Studi pada Pemerintah Riau). Jurnal Sorot. Vol. 9 No. 1, April, hal 1121.

Hapsari, Nanda. 2011. Pengaruh Partisipasi Penyusunan Anggaran Terhadap Kinerja Manajerial Dengan Komitmen Organisasi Dan Locus of Control Sebagai Variabel Moderating (Studi Kasus Pada PT. Adhi Karya (Persero) Tbk. Divisi Konstruksi I). Universitas Diponegoro. Semarang.

Hery. 2014. Analisis Laporan Keuangan. Edisi Pertama. Penerbit Bumi Aksara. Jakarta.

Hullah, Abdurahman R. 2012. Pengaruh Sumber Daya Manusia dan Pemanfaatan Teknologi Informasi terhadap Keterandalan Pelaporan Keuangan pada Pemerintah Provinsi Sulawesi Utara. Jurnal Riset Akuntansi dan Auditing. Vol. 3 No. 2, Desember.

Komarasari, Warih, 2017. Pengaruh Kapasitas Sumber Daya Manusia, Pemanfaatan Teknologi Informasi Dan Pengendalian Intern Akuntansi Terhadap Keterandalan Pelaporan Keuangan Daerah (Pada SKPD Kabupaten Bantul Bagian Akuntansi dan Keuangan). Universitas PGRI Yogyakarta. Yogyakarta

Nivo, Wulandari. 2013. Pengaruh Partisipasi Anggaran Dan Komitmen Orgaisasi Terhadap Kinerja Aparat Pemerintah Daerah. Skripsi. Fakultas Ekonomi Universitas Negeri Padang

Ridwan dan Ratifah,Ifa, Komitmen Organisasi Memoderasi Pengaruh Sistem Akuntansi Keuangan Daerah terhadap Kualitas Laporan Keuangan.Trikonomika Volume 11, No 1, Edisi Juni 2012. ISSN 1411-514X

Sugiyono. 2016. Metode Penelitian Kuantitatif, Kualitatif, dan R\&D. Alfabeta. Bandung.

Sujarweni, V. Wiratna. 2015. Akuntansi Sektor Publik: Teori, Konsep, Aplikasi. Penerbit Pustaka Baru, Yogyakarta.

Sumarsan, Thomas. 2013. "Akuntansi Dasar dan Aplikasi dalam Bisnis Versi IFRS". Jakarta: Indeks

Swasana, Dwi. 2016. Pengaruh Kapasitas Sumber Daya Manusia, Pemanfaatan Teknologi Informasi, dan Sistem Pengendalian Intern Terhadap Nilai Informasi. Universitas Diponegoro. Semarang.

Yusuf, M. 2013. Delapan Langkah Pengelolaan Aset Daerah Menuju Pengelolan Keuangan Daerah Terbaik. Penerbit Salemba Empat. Jakarta.

Zuliarti. 2012. Pengaruh Kapasitas Sumber Daya Manusia, Pemanfaatan Teknologi Informasi, dan Pengendalian Intern Akuntansi Terhadap Nilai Informasi Laporan Keuangan Pemerintah Daerah : Studi Pada Pemerintah Kabupaten Kudus. Universitas Muria Kudus, Kudus. 